\title{
Escândalo Político e Narratologia: tecendo os fios narrativos dos casos Face Oculta e Lava Jato ${ }^{1}$
}

\section{Political Scandal and Narratology: weaving the narrative threads of Face Oculta and Lava Jato cases}

Hélder Prior

Universidade da Beira Interior (UBI)

$<$ helder.prior@gmail.com>

\section{RESUMO}

Este trabalho propõe o uso da teoria da narrativa para a interpretação dos escândalos midiáticos. Acreditamos que, juntando notícias sobre um mesmo tema ou assunto publicadas de forma dispersa durante vários meses, é possível tecer os fios narrativos de dois escândalos em particular, os casos Face Oculta (Portugal) e Lava Jato (Brasil) e, assim, reconfigurar os acontecimentos numa trama que nos permite compreender melhor a configuração dos escândalos políticos nos dispositivos de mediação simbólica. Prestando especial atenção ao plano da estória e ao plano do discurso, em um processo de co-construção da realidade midiática, pretendemos observar o desenvolvimento do escândalo na imprensa, o seu desdobramento em plots principais e secundários, a construção e caracterização das dramatis personae e os efeitos poéticos ou estéticos inerentes às estratégias enunciativas do campo do jornalismo no momento de costurar o acontecimento. Deste modo, o artigo analisa o momento da eclosão dos dois casos e a sua posterior reconfiguração semântica, deixando a antever as similaridades e as diferenças da imprensa portuguesa e brasileira na interpretação e instituição dos escândalos políticos.

\begin{abstract}
This work aims to analyze the configuration of the mediated scandals through the narrative theory. We believe that by combining news stories about the same subject or topic published in a dispersive way for several months, its possible to weave the narrative threads of two particular scandals: Face Oculta (Portugal) and Lava Jato (Brazil) and, as consequence, reconfigure the events in a plot that allows us to understand the political scandals as media events. Paying particular attention to the discourse strand (expression plane) and to the story-strand (chronological events in a narrative), we pretend to assume that political scandals are complex narratives that may be interpreted as stories that have a plot, minor and major episodes, characters and poetic and aesthetic effects inherent to meaning strategies of the journalism field in the moment of converting the scandal into a media experience. Besides that, we also verify the similarities and differences in interpretations of both cases.
\end{abstract}

Keywords: Political Scandal. Narrative Theory. Political Journalism.

\section{Introdução}

Os escândalos políticos têm-se configurado como uma característica proeminente da vida pública das democracias contemporâneas, um fenômeno que, como se sabe, está relacionado com evidentes transformações do espaço

1 Pesquisa financiada pela Fundação para a Ciência e a Tecnologia, República Portuguesa, Ciência, Tecnologia e Ensino Superior. 
público, particularmente com a transformação da publicidade ou visibilidade do poder, com o surgimento do jornalismo de investigação, com a midiatização da esfera política, mas também com a diluição das fronteiras seculares entre a esfera pública e a esfera privada. Muitas vezes, os escândalos políticos desvelam casos de perversão ou corrupção do poder público, concedendo visibilidade a episódios de corrupção, a patologias ou disfunções das democracias liberais. Todavia, em outras situações, o que se destaca é o papel dos meios de comunicação na revelação, publicitação e reconfiguração de um acontecimento que se desenvolve como uma complexa trama midiática que alimenta o imaginário do público e que converte o fenômeno em um evento complexo que se reconfigura nos dispositivos de mediação simbólica.

Efetivamente, podemos considerar que, ao escândalo, é inerente uma dinâmica comunicativa que acaba por contribuir para a midiatização e para a dramatização de um acontecimento urdido pelas estratégias da máquina narrativa do medium. Assim, este trabalho é uma tentativa de compreender os escândalos midiáticos à luz dos pressupostos da teoria da narrativa. Em um primeiro momento, procuraremos definir o conceito escândalo e identificar as suas características tendo em conta o contributo dos principais autores que trabalharam o fenômeno. Posteriormente, iremos tecer algumas considerações sobre as relações entre o escândalo e a narratologia, estabelecendo um quadro teórico que nos possibilitará, no terceiro ponto deste ensaio, realizar uma análise pragmática dos escândalos Face Oculta (Portugal) e Lava Jato (Brasil).

Para a refiguração narrativa do caso Face Oculta, foram analisadas as edições publicadas no Semanário Sol de 6 de Novembro de 2009 a 5 de Novembro de 2010. No que se refere ao escândalo Lava Jato, o período analisado reporta-se às primeiras denúncias publicadas na edição de 19 fevereiro de 2014 da revista Veja e estende-se até a edição de 29 de outubro do mesmo ano, publicada na véspera do segundo turno das eleições presidenciais. $O$ recorte temporal analisado refere-se ao momento da eclosão de ambos os escândalos até o seu posterior desdobramento numa narrativa mais complexa. Tal recorte possibilita-nos observar a configuração inicial dos dois casos, mas também o papel das denúncias secundárias na reconfiguração semântica dos acontecimentos operada pelo campo do jornalismo. No caso do escândalo Face Oculta, foram analisadas 25 edições do Semanário Sol e um total de 63 notícias. Para a refiguração parcial do caso Lava Jato, analisamos 27 edições da revista Veja e um total de 40 matérias sobre o escândalo. Quer o Semanário Sol, quer a revista Veja, dedicaram bastante espaço à cobertura dos dois escândalos de corrupção, desempenhando um papel determinante na progressão dos 
escândalos e no adensar das respectivas narrativas, algo que ajuda a explicar a escolha dos títulos analisados.

Com efeito, pretendemos concentrara nossa atenção nas denúnciasiniciais e na posterior reconfiguração dos escândalos inerente ao seu desdobramento, deixando a antever algumas pistas para a interpretação dos escândalos mediante os pressupostos da narratologia. O objetivo é o de demonstrar que os escândalos políticos podem ser interpretados como narrativas que têm um enredo, episódios principais e secundários, personagens que realizam papéis ou funções na trama e efeitos poéticos ou estéticos inerentes às estratégias enunciativas do campo do jornalismo no momento de costurar o acontecimento em uma experiência midiática. Para isso, prestaremos especial atenção a duas instâncias de análise em particular, o plano da estória (enredo, ações, serialidade e personagens) e o plano do discurso (ardis enunciativos que visam evocar a realidade), no sentido de tecer os fios narrativos dos dois escândalos. Os procedimentos operativos seguem alguns dos movimentos empíricos sugeridos pela análise pragmática da narrativa jornalística (Motta, 2013) e pela proposta da análise das narrativas midiáticas apontada por Lits (2008), reunindo contributos da lingüística, dos estudos literários e da hermenêutica, e considerando o texto em uma perspectiva sócio semiótica, o que pressupõe um sujeito ativo no processo de co-construção da realidade midiática.

\section{O Escândalo Político}

O escândalo tem uma tradição secular, comprovada, de resto, pela própria etimologia do conceito oriunda da tradição teológica. A palavra grega skándalon foi originalmente utilizada para designar uma "ocasião de tropeço", uma "armadilha" ou um momento de fraqueza, de "queda no erro", que pode conduzir à "queda" ou à "ruína".2 De acordo com o Antigo Testamento, a expressão refere uma conduta pecaminosa, uma "indignação produzida pelos maus exemplos" (Figueiredo, 1996, p. 1015). ${ }^{3}$

Porém, o conceito acabou por adquirir uma conotação mais sociológica do que religiosa, passando a significar uma ofensa às normas societais dentro de um determinado contexto cultural, a derrogação dessas normas, ou um comportamento condenável que pode afetar a reputação dos indivíduos implicados nesse comportamento. Na atualidade, o escândalo tem sido compreendido quer como uma ação que viola determinados preceitos éticos, morais, sociais, culturais ou políticos, quer como a indignação produzida por

2 Não tornemos, pois, a julgar-nos uns aos outros, julgai antes que não se deve proporcionar ocasião de tropeço ou de queda a um irmão (Carta aos Romanos, 14:13).

3 Conforme a Bíblia (São Lucas, 7:23; Isaías, 8:15). 
essa violação ou derrogação na opinião pública. Do ponto de vista político, Markovits e Silverstein (1988) definem o escândalo como a violação dos procedimentos normativos que regulam o exercício do poder nas democracias liberais, procedimentos que definem o jogo político como sendo "aberto" e "acessível". Os autores sublinham que o escândalo político resulta da intersecção entre a lógica do poder, tendencialmente "secreta" e "exclusiva", e a lógica do "procedimento devido" que regula o exercício do poder nas democracias, necessariamente"aberta","pública”e"inclusiva”(Markovits; Silverstein, 1988, p. 7).

Porém, enquanto Markovits e Silverstein (1988) colocam a ênfase na transgressão ou na violação dos procedimentos que regem o exercício do poder, Jímenez Sanchéz (1995) define o escândalo como uma"reação da opinião pública contra a conduta de um determinado agente político responsável por abuso de poder ou pela violação da confiança social depositada em si pelos cidadãos"4 (Sanchéz, 1995, p. 23, tradução nossa), colocando a ênfase do fenômeno nos sentimentos de indignação provocados por uma conduta "pecaminosa".

Todavia, podemos considerar que a definição mais sistematizada do conceito nos é oferecida pelo sociólogo britânico John B. Thompson (2001) na influente obra O Escândalo Político: poder e visibilidade na era da mídia. Para Thompson, geralmente os escândalos têm cinco características: a) o escândalo implica a existência da transgressão de certos valores, normas ou códigos morais; b) o escândalo implica um certo nível de segredo sobre essa transgressão, segredo que, no entanto, é desvelado por indivíduos que não estão diretamente implicados, definidos como "não participantes"; c) alguns indivíduos reprovam essas ações ou acontecimentos e podem sentir-se ofendidos pela transgressão; d) alguns "não participantes" expressam publicamente a sua desaprovação, tornando públicos os acontecimentos; e) a revelação das transgressões e a eventual condenação da opinião pública podem afetar a reputação dos indivíduos que se encontram no epicentro do escândalo ${ }^{5}$ (Thompson, 2001, p. 32, tradução nossa).

4 No original: cabe definir el escándalo político como una reacción de la opinión pública contra un agente político al que se considera responsable de una conducta que es contemplada como un abuso de poder o una violación de la confianza social sobre la que se basal a posición de autoridad que mantiene o puede llegar a mantener tal agente.

5 No original: Para ser más exactos, yo sugeriría que, en su uso corriente, escándalo se refiere principalmente a las acciones, acontecimientos o circunstancias que poseen las siguientes características: a) su ocurrencia o existencia implica la transgresión de ciertos valores, normas o códigos morales; b) su ocurrencia o existencia implica un elemento de secreto o de ocultación, pero ello no obstante llegan a ser conocidos por individuos distintos a los directamente implicados; o bien esos individuos tienen motivos para creer fundadamente que existen tales elementos de secreto u ocultación (me referiré a estos individuos con la expresión "no participantes)"; c) algunos no participantes desaprueban las acciones o los acontecimientos y pueden sentirse ofendidos por la transgresión; d) algunos no participantes expresan su desaprobación 
Com efeito, nas mais recentes décadas, particularmente a partir dos anos 60, o escândalo político converteu-se em uma característica incontornável da esfera política de muitas democracias liberais. Em uma explicação mais simplista, podemos considerar que a prevalência do escândalo político se deve a um declínio dos preceitos morais dos dirigentes políticos ou da atividade política. Porém, o próprio Thompson (2007) considera que a proeminência do escândalo se deve mais a alterações dos códigos morais e das convenções que regem o exercício do poder, e a uma conseqüente importância cada vez maior desses códigos e convenções, do que propriamente a um declínio da moral pública. Na perspectiva do autor, podemos apontar cinco importantes alterações que nos ajudam a compreender a proeminência do escândalo político nas modernas democracias liberais: 1) o aumento da visibilidade pública dos dirigentes políticos; 2) o surgimento de modernas tecnologias de vigilância e controlo; 3) transformações na cultura jornalística; 4) transformações na cultura política; 5) maior legalização dos procedimentos institucionais que regem a atividade política e o controle do poder público.

Sabemosqueo desenvolvimento dasformas midiatizadas de comunicação gerou um novo tipo de visibilidade pública que já não está dependente da partilha do mesmo sistema de referência espaço-temporal, nem de formas de interação face a face, como acontecia, por exemplo, no espaço público da era Moderna pautado por aquilo que Habermas (2006) designou de publicidade representativa. Naquela época, a visibilidade dos atores políticos dependia da partilha do mesmo contexto espacial e temporal, mas o desenvolvimento das formas midiatizadas de comunicação ampliou a visibilidade dos dirigentes políticos e a conseqüente publicidade das suas ações. Se, por um lado, os dirigentes políticos passaram a beneficiar de novas formas de comunicação midiatizada para fazer chegar as suas mensagens a uma audiência bastante ampla, o florescimento da nova visibilidade originou um novo tipo de intimidade na esfera pública, contribuindo para esbater as fronteiras tradicionais entre o público e o privado. Por conseguinte, a chamada "sociedade da auto-revelação" contribuiu, de certa forma, para privatizar o espaço público, pois os dirigentes políticos passaram a revelar aspectos que outrora ficavam resguardados na esfera da privacidade. Como consequência, esta nova forma de exposição gerou novos riscos para os atores políticos, pois ao apresentarem-se em público e ao revelarem aspectos relacionados com o seu caráter, cultivando uma determinada imagem pessoal ou familiar, mais facilmente podem ser

denunciando públicamente las acciones o los acontecimentos; e) la revelación de las acciones o los acontecimientos y la condena que recae sobre la conducta pueden dañar la reputación de los individuos responsables (aunque no siempre ni necesariamente sea este el caso). 
condenados ou julgados quando determinadas falhas morais ou transgressões vêm a público. Na era da visibilidade midiatizada, os dirigentes políticos sabem perfeitamente que necessitam dos meios de comunicação como palco para conquistarem visibilidade pública e assentimento junto dos eleitores, mas deve referir-se que essa visibilidade se pode, perfeitamente, converter em uma armadilha (Prior, 2011).

O segundo ponto sublinhado por Thompson (2007) está intrinsecamente relacionado com a transformação da visibilidade. Como se sabe, o desenvolvimento das modernas tecnologias de vigilância, espionagem e controle tornou bastante difícil a ocultação de determinadas transgressões e um certo cultivo do segredo típico dos bastidores da esfera da ação política. Neste sentido, fatos ou acontecimentos que deveriam permanecer na esfera secreta são publicitados e explorados pelos meios de comunicação, eclodindo na esfera pública sob a fórmula do escândalo midiático. Quanto às transformações ocorridas na cultura jornalística, o sociólogo destaca o papel do jornalismo de investigação, particularmente a partir dos anos 60 e 70, na criação de um contexto onde a procura de informações secretas sobre as atividades dos dirigentes políticos e a sua consequente publicitação na imprensa passou a ter bastante relevância jornalística, fundamentalmente quando essas informações se revestem do famigerado interesse público.

De outro modo, existem algumas transformações na própria esfera política que ajudam a explicar o fato de o escândalo ter adquirido bastante relevância na vida pública contemporânea. Neste ponto, o autor sublinha que o escândalo político converte-se em uma espécie de "teste de credibilidade" (Thompson, 2007, p. 264) para os atores políticos. A vida pública passou a orientar-se cada vez mais pelo ethos e pela integridade do homo politicus. É por isso que as transgressões cometidas na esfera privada se converteram em algo tão relevante no julgamento que o público faz dos dirigentes políticos, particularmente quando a imagem pública projetada por esses dirigentes não está de acordo com o comportamento que estes têm na sua vida privada ou com as convenções sociais tácita ou explicitamente adotadas.

Por último, deve destacar-se o surgimento e a cada vez maior importância dada aos mecanismos legais e parlamentares de escrutínio da esfera política. A existência de comissões parlamentares de inquérito destinadas a averiguar eventuais desvios dos dirigentes políticos, bem como outras formas de controlo típicas das democracias liberais, também ajudam a explicar a proeminência do escândalo nas sociedades hodiernas. Neste ponto, autores como Markovits e Silverstein (1988) consideram mesmo que o escândalo político só pode ocorrer nas democracias liberais, pois estas sustentam-se fundamentalmente em 
sólidos procedimentos normativos e institucionais que regulam o exercício do poder político.

\section{Escândalo midiático e narratividade}

Interpretar o escândalo político à luz da teoria da narrativa implica o reconhecimento de alguns problemas conceptuais. Como se sabe, o texto jornalístico, particularmente o texto noticioso é, por natureza, revestido de uma linguagem "dura", uma linguagem objetivada e eminentemente descritiva e direta (Motta, 2013, p. 95-96). ${ }^{6}$ A atividade jornalística pressupõe a descrição da realidade da vida de todos os dias, uma realidade que, muitas vezes, deve ser "desvelada" ou "descortinada" pelo jornalista, até porque os fatos nem sempre se encontram à "superfície", particularmente os fatos sobre a realidade política. Todavia, a descrição dessa realidade que se quer narrar, a linguagem jornalística, deve, necessariamente, ter uma relação com o referente ausente, com o referente empírico. Não devemos esquecer que a intenção comunicativa da linguagem jornalística é sempre a de produzir um discurso verídico e, consequentemente, a de despertar os chamados efeitos de real ou efeitos de realidade. É por isso que a maior parte dos relatos da imprensa que nos surgem no quotidiano são pautados por um estilo "duro", "direto", "conciso", "objetivo" e pouco permeado por manifestações subjetivas. O jornalista deve, no chamado lead da notícia, responder de forma simples e direta às questões "o quê", "quem", "quando","onde", "como" e "por quê", aproximando o leitor da realidade ou do acontecimento reportado. Neste sentido, identificar elementos narrativos, estéticos e poéticos nas chamadas hardnews, é um desafio aliciante para o analista.

Apesar de alguma imprensa brasileira, sobretudo a revista Veja que, de resto, nos serve de ilustração empírica, se pautar por certos critérios subjetivos de atuação, dotando muitas vezes as notícias da realidade política de elementos narrativos, encontrar a lógica narrativa inerente aos escândalos midiáticos nas "duras" e "cruas" notícias do dia-a-dia só é possível se nos detivermos sobre o modo como essas notícias "lidam com o tempo" e o organizam com o objetivo de reconstruir o acontecimento numa sequência lógica e ordenada. Como sublinha Gonzaga Motta:

6 Apesar de ser possível identificar elementos narrativos nas notícias do dia-a-dia, particularmente nas notícias de interesse humano e nos chamados fait divers, a reportagem é o gênero jornalístico mais facilmente permeável às estratégias da dramaticidade e aos chamados efeitos poéticos ou estéticos. 
O tempo no relato jornalístico é difuso, anárquico, invertido. Por isso, a lógica e a sintaxe narrativas só despontarão se pudermos reconfigurar os relatos como unidades temáticas, intrigas que contenham princípio, meio e final de uma estória única (como aliás fazem, de maneira natural, os leitores, ouvintes e telespectadores nos atos de recepção) (Motta, 2013, p. 97).

Assim, para encontrarmos uma lógica narrativa nas chamadas hardnews, particularmente nas notícias sobre acontecimentos políticos, que são aquelas que aqui nos importa analisar, será necessário, antes de tudo, agrupar informações ou notícias sobre um mesmo tema, organizar temporalmente essas informações, pois podem estar separadas por intervalos de tempo relativamente longos, recompor o enredo, as sequências da intriga, identificar as personagens, enfim, juntar as pontas da estória e os respectivos encadeamentos entre essas pontas. Trata-se de "recompor o acontecimentointriga" (Motta, 2013, p. 98) e de dispor os acontecimentos em uma sequência temporal e causal, em uma sequência lógica. Não devemos esquecer que os escândalos político-midiáticos começam sempre pelo final da estória, quando uma transgressão cometida no passado se publicita, se converte em um acontecimento público. Tratando-se de narrativas eminentemente complexas, compete ao analista organizar os antecedentes da estória, contextualizar a transgressão, posicionar os indivíduos que se encontram no epicentro do escândalo, recompor a serialidade, os episódios, as sequências da intriga, identificar os efeitos de real e os efeitos de sentido inerentes ao ato de reportar um acontecimento e de o instituir. Só reunindo as notícias que vão surgindo sobre o acontecimento, na maioria das vezes a conta-gotas, em fragmentos dispersos e durante um período de tempo relativamente longo, é que podemos encontrar a totalidade significativa dos escândalos midiáticos mais complexos, embora se deva reconhecer a dificuldade metódica em reunir fragmentos de estórias sobre escândalos, devido à complexidade, ao desdobramento e ao desenvolvimento temporal bastante longo da maioria dos escândalos.

Por outro lado, a recomposição das notícias sobre um mesmo tema ou assunto num produto novo, o "acontecimento-intriga", permite compreender a mimese jornalística não apenas como uma atividade de representação do real, mas fundamentalmente como uma atividade produtora e instituidora de sentidos (Motta, 2013, p. 99-100). Quando o escândalo político emerge, constitui-se um complexo processo de comunicação midiática que consiste em um rol subsequente de revelações, acusações, reações de defesa, que têm uma característica particular: os acontecimentos são moldados pelos jornalistas e as 
estórias são criadas e reportadas tendo em conta "códigos narrativos" (Canel; Sanders, 2006). As narrativas jornalísticas são sempre constituídas por elementos referentes à vida social, mas o narrador desempenha um papel determinante na seleção e organização temporal das ações ou dos acontecimentos sociais, tendo sempre em conta um determinado propósito ao narrar ou uma determinada intenção comunicativa. Para narrar uma estória, particularmente uma estória complexa como é o caso da maioria dos escândalos, os jornalistas procuram criar um todo coerente, organizar os acontecimentos tendo em conta uma lógica espacial e temporal, uma lógica que, naturalmente, se ajusta ao ritmo de produção das organizações midiáticas. É aquilo a que os narratólogos chamam de "tessitura da intriga" (Correia, 2012, p. 34), no fundo, a atribuição de sentido a uma sucessão de ações e de acontecimentos no tempo. Como sublinham Canel e Sanders, "[...] nos escândalos midiáticos, estórias e personagens são criadas e qualidades atribuídas; as estórias têm plots e pontos de viragem; elas recebem uma ordem temporal com vista à criação de um todo coerente"7 (Canel; Sanders, 2006, p. 53, tradução nossa).

Porém, deve reconhecer-se que a sintaxe narrativa dos escândalos midiáticos dificilmente se revela à primeira vista. Será fundamental recuperar a sequência episódico-temporal dos acontecimentos, integrar as unidades temáticas e encontrar as microproposições dispersas recompondo um acontecimento unitário. Como refere Ricoeur (1986), tecer a intriga permite configurar a estória na sua totalidade, combinando as dimensões cronológica e configurante, obtendo uma síntese e uma totalidade temática. É necessário, portanto, construir uma espécie de "composição verbal" que converte um texto em narração, composição verbal que Ricoeur designa de "intriga" ou melhor, de "mise-en-intrigue", de organização da intriga. Correspondente a um plano de organização macroestrutural do texto, a intriga caracteriza-se pela apresentação dos eventos segundo determinadas estratégias discursivas que conduzem à progressão da história (Reis; Lopes, 1988): “[...] a intriga é o conjunto das combinações pelas quais há acontecimentos que são transformados em história ou - correlativamente - uma história é tirada de acontecimentos"8 (Ricouer, 1986, p. 16, tradução nossa).

Com efeito, só a partir da recomposição de notícias dispersas em uma intriga temática é que será possível analisar criticamente o processo de produção de sentidos inerente à atividade jornalística. Mediante ao encaixe e a

$7 \quad$ No original: In media scandals stories characters are created and qualities attributed. Stories have plots with turning points; they receive a specific temporal order to construct a coherent whole. 8 No original: l'intrigue est l'ensemble des combinaisons par lesquelles des événements sont transformés en histoire ou - corrélativement - une histoire est tirée d'événements". 
integração das unidades heterogêneas e fragmentadas em um todo homogêneo e unificado, o analista conseguirá chegar às significações mais profundas da narrativa jornalística, significações impregnadas de subjetividade presentes em relatos aparentemente objetivos, como é o caso de relatos sobre escândalos midiáticos. De acordo com Motta (2013, p. 103), trata-se da "[...] experiência estética da recepção jornalística onde esvaece o mundo fático e manifestase o mundo subjetivo das ideologias, mitos e modelos de mundos". Na nossa perspectiva, as narrativas sobre escândalos midiáticos são, particularmente, propensas ao desencadeamento de efeitos estéticos ou poéticos, de efeitos dramáticos. Ao referir-se à derrogação de valores morais, sociais, políticos, normativos ou religiosos, o escândalo midiático questiona a moralidade pública (Bird, 1997), coloca em causa normas e valores socialmente aceitos e partilhados e, acima de tudo, desperta efeitos dramáticos no público.

Efetivamente, partindo da análise dos atos de fala do narrador-jornalista é possível, muitas vezes, descortinar uma mensagem e um fundo ético nas narrativas sobre escândalos, um plano da estrutura de fundo que ajudará a compreender o sentido integral do acontecimento convertido em estória. Como resultado, as narrativas sobre escândalos midiáticos despertam a atenção pública e, muitas vezes, as "estórias noticiosas sobre escândalos convertem-se em contos morais"9 (Canel; Sanders, 2006, p. 54, tradução nossa).

Entendamos por isso que uma ação só é um começo numa estória que ela inaugura. $E$ também que qualquer ação só é um meio se ela provocar, na estória contada, uma mudança de destino, um "nó" para desatar, uma "peripécia" surpreendente, uma sucessão de incidentes "lamentáveis" ou "aterradores", finalmente, qualquer ação considerada em si mesma só é um fim quando, na estória contada, ela conclui o curso de uma ação, desata o nó, compensa a peripécia pelo reconhecimento, sela o destino do herói por um último acontecimento que clarifica toda a ação e produz no ouvinte a katharsis da piedade e do terror ${ }^{10}$ (Ricoeur, 1986, p. 16, tradução nossa).

9 No original: as a result media scandal stories become the center of public attention and news scandal stories become morality tales".

10 No original: comprenons par là qu'aucune action n'est un commencement que dans une histoire qu'elle inaugure; qu'aucune action n'est non plus un milieu que si elle provoque dans I'histoire racontée un changement de fortune, un noeud à dénouer, une "péripétie" surprenant, una suite d'incidents "pitoyables" ou "effrayants"; aucune action, enfin, prise en elle-même, n'est un fin, sinon en tant que dans l'histoire racontée elle conclut un cours d'áction, dénoue un noeud, compense la péripétie par la recommaissance, scelle le destin du héros par un événement ultime qui clarifie toute l'action et produit, chez l'auditeur, la katharsis de la pitié et de la terreur. 


\section{O Escândalo Face Oculta}

Analisando a cobertura do Semanário Sol em um período determinado, procuraremos compreender de que forma o ato de fala jornalístico organizou $o$ acontecimento, as suas sequências, a caracterização das personagens envolvidas na trama e o uso de determinadas artimanhas enunciativas que visaram criar efeitos de real e efeitos de sentido. Por um lado, a análise permite-nos observar a recomposição de notícias sobre um mesmo tema ou acontecimento dramático onde é possível acompanhar a representação do real. Por outro, também nos permitirá compreender os escândalos midiáticos como narrativas jornalísticas que se vão desdobrando em episódios aos quais a poética noticiosa vai acrescentando novos elementos que aumentam a sua complexidade.

No caso particular do escândalo que ficou conhecido por Face Oculta, podemos asseverar que se enquadra, pelo menos de acordo com a categorização proposta por John Thompson (2001) na tipologia de escândalo político-financeiro, uma vez que revelou a existência de laços ocultos entre o poder político e o poder econômico que serviriam para beneficiar empresas privadas mediante uma rede de corrupção e tráfico de influências. O escândalo eclodiu em outubro de 2009 e culminou em setembro de 2014 com a condenação de todos os argüidos, embora tivesse voltado à agenda midiática em novembro de 2016. ${ }^{11}$ Os tribunais deram como provada a existência de uma organização criminosa de "rede tentacular" que visava beneficiar a empresa $\mathrm{O} 2$ do sucateiro Manuel Godinho' ${ }^{12}$ mediante concursos públicos manipulados nos quais intervieram altos quadros do governo português liderado, na época, por José Sócrates. Todavia, é interessante constatar que apesar desta aparente linearidade, o caso se desenvolveu como uma complexa narrativa midiática que reconfigurou substancialmente a compreensão do acontecimento. É que das, escutas telefônicas realizadas durante as investigações a Armando Vara ${ }^{13}$, um

11 No dia 22 de novembro, o Jornal I e o Sol on-line noticiaram que a equipa da Operação Marquês, no âmbito da investigação a outro escândalo envolvendo José Sócrates, descobriu novas evidências acerca do alegado plano do ex-primeiro-ministro para controlar a estação televisiva TVI. O plano teria sido batizado de Projeto Aljubarrota, em uma alusão à empresa espanhola Prisa, detentora da estação televisiva, e à histórica batalha de 1385 que dividiu o Reino de Portugal do Reino de Castela e Leão.

12 Manuel Godinho foi condenado pelos crimes de associação criminosa, corrupção ativa para ato ilícito e tráfico de influências. Empresário do sector privado, Manuel Godinho financiou campanhas do Partido Socialista.

13 Armando Vara foi deputado na Assembleia da República, secretário de Estado, ministro da Juventude e do Desporto (2000), e administrador dos Bancos Millennium/Banco Comercial Português e Caixa Geral de Depósitos, onde exerceu a sua influência para conceder crédito ilícito. Esteve envolvido nos processos Face Oculta e Operação Marquês, outro escândalo de corrupção que envolve a governação de José Sócrates. Foi condenado à prisão efetiva no âmbito do escândalo Face Oculta por crimes de tráfico de influências. 
dos envolvidos no esquema, faziam parte conversas entre esse personagem e o primeiro-ministro José Sócrates, conversas que segundo o Ministério Público levantavam suspeitas de que o governo teria tentado utilizar e empresa Portugal Telecom (PT) para comprar a estação televisiva TVI e, assim, influir no conteúdo das notícias. Isto é, as escutas revelaram a existência de "transgressões de segunda ordem" que pouco tinham que ver com as revelações iniciais que estiveram na origem da eclosão do caso e que converteram o Face Oculta numa complexa trama jurídico-midiática.

Com efeito, a análise da cobertura do SemanárioSo/ permite-nos recompor as sequências do escândalo, identificar as personagens envolvidas, reordenar a cronologia, recompor o enredo, ligar as partes, refigurando uma estória jornalística e identificando uma certa totalidade significativa fundamental para compreendermos o acontecimento. Como, de resto, refere Gonzaga Motta (2013, p. 99), "[...] a reconfiguração do acontecimento-intriga tem o mágico poder de tecer a totalidade da estória e realizar a função de integração e de mediação da intriga". Combinando eventos noticiosos dispersos, é possível criar uma nova síntese ou um novo acontecimento dramático. É a partir deste novo acontecimento dramático gerado pela recomposição de notícias fáticas e dispersas ao longo do tempo que podemos chegar ao micronível dos processos narrativos, isto é, aos enquadramentos do narrador, à identificação e disposição de personagens, aos conflitos, episódios e núcleos temáticos menores e, também, aos jogos de linguagem e aos efeitos de sentido.

A complexidade e o desdobramento do escândalo Face Oculta tornamse visíveis a partir da edição de 6 de novembro de 2009. O jornal sublinha, ainda sem grandes desenvolvimentos, que das escutas telefônicas efetuadas a Armando Vara surgiram "novos indícios" que estariam a ser analisados pelo então procurador-geral da República relacionados a um negócio que envolvia e empresa Portugal Telecom e a estação televisiva TVI. Desdobramento que é, sobretudo, confirmado pelas duas primeiras edições de fevereiro de 2010. A edição de 5 de fevereiro intitulada "As escutas proibidas", revela a existência de um plano que envolvia o primeiro-ministro para controlar a TVI e outros grupos de imprensa. De acordo com as novas revelações que adensam o caso, o plano passava por afastar a jornalista Manuela Moura Guedes da TVI, alegadamente devido à cobertura do Jornal Nacional de Sexta sobre outro escândalo que envolveu Sócrates, o caso Freeport ${ }^{14}$. O jornal fala de um plano concebido pelo

14 O caso Freeport eclodiu em 2005, em véspera de eleições legislativas, e refere-se a alegados subornos para viabilizar o projeto do outlet, aprovado quando José Sócrates era ministro do Ambiente do governo liderado por António Guterres. A polícia inglesa suspeitou que o intermediário inglês Charles Smith terá distribuído "luvas" (propina) por várias pessoas, entre 
então primeiro-ministro e por homens da sua confiança, que envolvia a compra da TVI pela PT, um esquema que configuraria o crime de atentado contra o Estado de direito ${ }^{15}$, já que o governo teria tentado subverter o Estado Constitucional e colocar em causa a liberdade de imprensa.

Um dos aspectos mais interessantes dos escândalos midiáticos, particularmente dos escândalos mais complexos, é a identificação de episódios que se diluem no interior da intriga, alguns sucedendo-se de forma linear e outros configurando-se como escândalos relativamente autônomos. Os escândalos são narrativas dinâmicas e a identificação temática é um movimento essencial na compreensão da sua totalidade significativa. Por conseguinte, o caso Face Oculta é paradigmático na identificação de unidades temáticas ou de estruturas semânticas que fizeram progredir a estória. Deve referir-se, não obstante, que estes núcleos temáticos são normalmente articulados pelo narrador-jornalista com vista à produção de determinados efeitos de sentido.

Os episódios referem-se a sequências coesas com relativa autonomia no interior de um relato e com início, meio e fim. São "unidades semânticas" que funcionam como organizadores do discurso e que permitem ao leitor fazer inferências relativas à trama (Motta, 2013, p. 163-164). Se a intriga que identificamos é a estrutura maior ou macroestrutura semântica, é o tema ou assunto do discurso, também designado por Van Dijk (Van Dijk, 1998) de macroproposição, é possível, todavia, identificar sequências ou "átomos narrativos" unidos por uma relação de solidariedade e contiguidade.

$\mathrm{Na}$ análise da cobertura do Semanário Sol, são vários os episódios que confirmam a serialidade dos escândalos midiáticos. Desses "átomos narrativos", um dos mais relevantes foi o caso da "mentira parlamentar" de José Sócrates. Trata-se de uma unidade temática de certa forma autônoma em relação às "transgressões de primeira ordem". Num debate parlamentar, o então primeiroministro foi confrontado com a hipótese da PT adquirir a estação televisiva, tendo em conta notícias que começavam a circular na imprensa sobre o negócio. Deputados do Centro Democrático Social/Partido Popular (CDS-PP) e do Bloco

as quais Sócrates, para que a construção do centro comercial de Alcochete fosse viabilizada. $O$ caso foi arquivado, mas teve grande impacto na agenda midiática portuguesa, nomeadamente no jornal Nacional transmitido pela estação TVI.

15 O crime de atentado contra o Estado de direito está previsto no Art. $9^{\circ}$ dos Crimes de Responsabilidade de Cargos Políticos: "o titular de cargo político que, com flagrante desvio ou abuso das suas funções ou com grave violação dos inerentes deveres, ainda que por meio não violento nem de ameaça de violência, tentar destruir, alterar ou subverter o Estado de direito constitucionalmente estabelecido, nomeadamente os direitos, liberdades e garantias estabelecidos na Constituição da República, na Declaração Universal dos Direitos do Homem e na Convenção Europeia dos Direitos do Homem, será punido com prisão de dois a oito anos, ou de um a quatro anos, se o efeito se não tiver seguido". 
de Esquerda (BE), questionaram se o negócio não poderia ser interpretado como o regresso do Estado à imprensa privada, mas José Sócrates afirmou que o governo não tinha recebido nenhuma informação sobre o assunto. $\mathrm{A}$ afirmação de Sócrates causou alguma estranheza nos políticos da oposição, com Manuela Ferreira Leite (Partido Social Democrata) e Francisco Louçã (BE) a considerarem "implausível" e "ingênuo" que o governo desconhecesse um negócio de 150 milhões de euros que envolvia uma empresa onde o Estado estava representado. O caso levou ao pronunciamento do então Presidente da República, Cavaco Silva, que pediu "ética nos negócios" e o governo de Sócrates acabou por vetar a compra da TVI pela PT no dia 24 de junho, no sentido de procurar eliminar suspeitas de intromissão do governo nos grupos de mídia.

Não obstante, o caso haveria de voltar à agenda pública em Novembro do mesmo ano. Segundo o Sol, as escutas do processo "[...] provam que o primeiroministro faltou deliberadamente à verdade" quando disse no Parlamento que desconhecia o negócio, já que,"conversas havidas entreVara eSócrates em março já versavam sobre este tema" [...] (O Sol, p. 4-5). O episódio da mentira parlamentar levou à abertura de uma Comissão Parlamentar de Inquérito (CPI) destinada a averiguar se José Sócrates mentira num órgão de soberania, CPI que concluiu

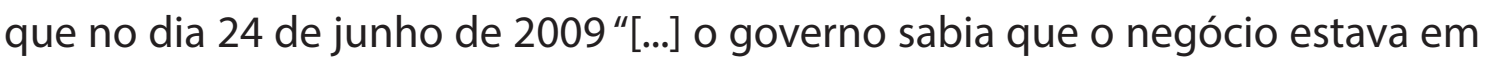
curso [...]"16 (Relatório, 2010, p. 148). Mas, ao longo da cobertura existem outros episódios igualmente relevantes e que ajudaram a reforçar a complexidade e o desdobramento da trama. O fim do Jornal Nacional de Sexta e a saída de Manuela Moura Guedes da estação televisiva ${ }^{17}$, ou o escândalo Taguspark e o polêmico apoio do ex-futebolista Luís Figo a José Sócrates nas eleições de $2009^{18}$ são, podemos dizer, episódios secundários do escândalo Face Oculta. Definidos o eixo da estória e os seus episódios, uma outra categoria narrativa que nos importa tem que ver com a personalização do escândalo. De acordo com Todorov (1979), na sequência narrativa cada capítulo é constituído em torno de uma determinada ação e, por conseguinte, de uma personagem,

16 Vide: Relatório final da Comissão eventual de Inquérito Parlamentar relativa à relação do Estado com a Comunicação Social e, nomeadamente, à atuação do Governo na compra da TVI. 17 A administração da TVI decidiu suspender a transmissão do Jornal Nacional de Sexta apresentado por Manuel Moura Guedes e o caso levantou suspeitas de intromissão do governo e de pressão política. José Sócrates considerou que o jornal era uma "caça ao homem", devido ao fato do jornal de sexta-feira apresentar semanalmente novos dados sobre o escândalo Freeport, que também envolveu o ex-primeiro-ministro. A oposição acusou o governo de censura.

18 O caso Taguspark diz respeito a eventuais contrapartidas que a administração do parque tecnológico situado em Oeiras, por intermediação de Rui Pedro Soares, teria dado ao exfutebolista Luís Figo para este apoiar a candidatura de José Sócrates nas eleições legislativas de 2009. O processo foi iniciado na sequência de uma certidão extraída do processo Face Oculta e em causa estava um contrato no valor de 350 mil euros por ano para que Figo promovesse internacionalmente a imagem do parque tecnológico. 
isto é, de elementos responsáveis pelo desempenho do enredo, pelos atos ativos ou passivos no interior de uma narrativa. Tal como sublinha o autor: "Não há personagens fora da acção, nem acção independente de personagens" (Todorov, 1979, p. 119). Trata-se do "reino dos homens-narrativas" (Todorov, 1979, p. 123) já que, como sustenta Motta (2013, p. 173), as personagens são "elementos-chave na projeção da estória e na identificação dos leitores com o que está sendo narrado", sendo que sem personagens não poderia existir estória.

Assim, o escândalo Face Oculta teve, necessariamente, os seus protagonistas e a personalização do escândalo é visível, por exemplo, na edição de 6 de novembro de 2009 quando o narrador posiciona as personagens da intriga recorrendo a um enquadramento lúdico. Com o título "A teia de influências do Face Oculta", (p. 4) o narrador identifica as personagens e os seus papéis na trama, personaliza o enredo e, simultaneamente, coloca José Sócrates como "actante dominante" da narrativa. De resto, a centralidade midiática de José Sócrates é novamente visível na edição de 12 de fevereiro de 2010, num novo enquadramento lúdico-metafórico. Recorrendo à metáfora do "polvo", um dos enquadramentos lúdicos típicos do jornalismo político, particularmente da cobertura de casos de corrupção, o jornal identifica o ex-primeiro-ministro como figura central da narrativa, como responsável por uma "rede tentacular" que visava controlar grupos de comunicação social. Em termos discursivos, trata-se de um enquadramento metafórico que tem não apenas a função de "ornamentar" o discurso jornalístico, mas também a função de despertar efeitos de sentido no público, de captar e reter a sua atenção.

De outro modo, no movimento de identificação das personagens da trama, o jornalista-narrador recorre a determinadas estratégias narrativas para caracterizar as personagens do enredo. A idéia é a de que o leitor, no ato de apreensão do texto, atribui, consciente ou inconscientemente, um determinado caráter às personagens que se movem no interior da intriga. Através de "ardis enunciativos", o sujeito-narrador vai qualificando as personagens (Motta, 2013, p. 177) e estimulando interpretações na audiência. No caso do Face Oculta, Rui Pedro Soares, administrador da PT nomeado pelo governo e um dos responsáveis nos bastidores pelo negócio PT/TVl, é caracterizado como um "boy sem curriculum" (12/02/2010, p. 9) para ocupar o cargo de administrador da empresa.

Efetivamente, é notório como no projeto dramático do narrador, a identificação e caracterização das personagens surge como eminente categoria, mas sempre mediante ardis enunciativos que permitem identificar qualidades ou defeitos, mais defeitos do que, propriamente, qualidades. Ou seja, as personagens são criadas pelo poder de voz do sujeito narrador que, tal como 
sustenta Mesquita (2002), tende a reduzir a complexidade da descrição ou caracterização, procurando ilustrar ou confirmar os traços dos quais o narrador partiu inicialmente. Tal significa que os procedimentos retóricos aos quais o sujeito-narrador recorre, simplificam os traços característicos das personagens, criando, em alguns casos, actantes estereotipados em uma espécie de "mimesis rudimentar" que reduz a complexidade dos seres retratados (Mesquita, 2002, p. 126), e que, simultaneamente, permite que o leitor reconstrua o caráter da personagem em causa. Assim, é conveniente sublinhar que, se as personagens assumem determinados papéis e adquirem certas características, isso deve-se ao relato do narrador e à representação discursiva que este faz de figuras reais, mas discursivamente construídas.

\section{O Escândalo Lava Jato}

Não é despropositado afirmar que o escândalo Lava Jato se converteu no maior escândalo que a vida pública brasileira já conheceu. O caso eclodiu em março de 2014, a propósito de uma investigação das autoridades policiais acerca de uma rede criminosa de lavagem de dinheiro que utilizava postos de abastecimento de combustível e "lava a jato" para movimentar recursos financeiros ilícitos. Todavia, o desenvolvimento das investigações revelou um esquema criminoso que desviou, durante anos, dinheiro da petrolífera Petrobras, um esquema de corrupção que envolveu dirigentes da empresa, atores políticos, intermediários financeiros (doleiros) e grandes empreiteiras que operavam em "cartel", manipulando concursos públicos. Para o Ministério Público Federal, essas empresas pagavam subornos (propina) através de contratos combinados e superfaturados, dinheiro que era posteriormente distribuído pelos intermediários do esquema, dirigentes políticos e partidos com representação parlamentar, alguns da base aliada do governo petista.

O escândalo Lava Jato adquiriu uma nova dinâmica quando Paulo Roberto Costa, ex-diretor da empresa, e Alberto Youssef, operador do esquema de lavagem de dinheiro e responsável por distribuir os recursos desviados a partidos e políticos, acordaram com a justiça "delações premiadas"19 , explicando os pormenores do esquema de corrupção e identificando os dirigentes políticos envolvidos, em troca de eventuais reduções nas condenações judiciais.

As primeiras denúncias públicas surgiram, no caso da cobertura da revista Veja, na edição de 19 de fevereiro de 2014 e referem-se a alegados subornos por

19 A delação premiada está prevista na doutrina jurídica brasileira e refere-se a eventuais benefícios concedidos a um réu na redução de condenações judiciais. No caso da operação Lava Jato, os avanços nas investigações muito se devem às denúncias dos investigados que aceitaram colaborar com a justiça brasileira. 
parte de uma empresa holandesa (SBM), que teria pago "propina" a funcionários da Petrobras em troca de contratos para a exploração do pré-sal. Segundo Veja, a empresa holandesa teria pago 30 milhões de dólares para subornar funcionários da Petrobras (p. 57-59). As denúncias sobre corrupção na estatal adensam-se no mês seguinte com a publicitação, na edição publicada a 26 de março, de"negócios nebulosos e denúncias de corrupção" (p. 44) sobre a compra de uma refinaria em Pasadena, no Texas, aprovada quando Dilma Rousseff era conselheira da estatal. A Petrobras teria pago um valor demasiado elevado pela usina, o que originou investigações sobre crimes fiscais e super-faturação. Veja envolve a então presidente no negócio, embora na manchete da edição responsabilize, essencialmente, o "aparelhamento político" da Petrobras pela corrupção existente na estatal, visando, sobretudo, o Partido dos Trabalhadores. De acordo com a matéria, Dilma Rousseff teria dado aval favorável à compra da refinaria devido a um "parecer falho" que omitiu cláusulas do contrato que acabariam por prejudicar a Petrobras.

Como constatamos, o escândalo Lava Jato surge, inicialmente, devido a pequenas denúncias de corrupção na petrolífera, como o alegado suborno da empresa holandesa SBM ou o caso da compra da refinaria em Pasadena. Porém, importantes reconfigurações semânticas converteram o caso em um escândalo político de grandes proporções e que, de resto, ainda se encontra em desenvolvimento. Segundo denúncias publicadas por Veja nos meses de setembro e outubro, Paulo Roberto Costa confirmou a existência de um esquema de pagamento de subornos a deputados federais, senadores, governadores, um esquema que sustentava a base de apoio ao governo no Congresso e que teria sido idealizado no primeiro mandato do ex-presidente Lula da Silva. Por outro lado, na edição de 22 de outubro, Alberto Youssef declarou que a campanha presidencial do PT das eleições de 2010, que culminou na eleição de Dilma Rousseff, beneficiou de dinheiro desviado da Petrobras, naquela que se constituiu como uma das denúncias mais marcantes da operação Lava Jato no período analisado.

Na edição seguinte (24/10/2014), publicada na véspera do segundo turno das eleições de 2014, Veja coloca Dilma Rousseff e Lula da Silva no epicentro do escândalo com a polêmica manchete "Eles sabiam de tudo"20. De acordo com a revista, o doleiro da Lava Jato teria revelado à Polícia Federal e ao Ministério

20 Veja antecipou a publicação da sua edição semanal de domingo para sexta-feira, publicando uma reportagem onde afirmava que o doleiro Alberto Youssef teria declarado, no processo de delação premiada, que Dilma Rousseff e o ex-presidente Lula da Silva tinham conhecimento dos desvios de dinheiro na Petrobras. No mesmo dia, na propaganda eleitoral da TV, Dilma Rousseff criticou a revista e classificou a matéria e a antecipação da publicação como um ato de "terrorismo eleitoral". 
Público que Dilma Rousseffe Lula da Silva tinham conhecimento das "tenebrosas transações na estatal". Deste modo, de acordo com o enquadramento de Veja, aquilo que se iniciou com pequenas denúncias de corrupção na Petrobras, converteu-se numa complexa trama onde é visível que o PT, enquanto personagem coletiva e, sobretudo, Dilma Rousseff e Lula da Silva, adquirem uma notória centralidade, algo forçosamente relacionado com os próprios interesses editoriais da revista na cobertura do escândalo e no seu enquadramento.

Assim, se as primeiras denúncias concentraram a atenção pública nas transgressões iniciais, ao caso acabariam por ser acrescentadas novas denúncias ou "transgressões de segunda ordem" que acabariam por adensar o debate público e reconfigurar o acontecimento. Reconstruída a síntese da intriga, ou storyline, no que se refere ao período que nos importa analisar, é possível, com efeito, observar a serialidade temática do escândalo Lava Jato. A recomposição do "acontecimento-intriga" permite a identificação de episódios ou de unidades temáticas, até porque os escândalos midiáticos são, na maioria dos casos, narrativas complexas que se desdobram em núcleos temáticos menores diluídos no interior da intriga. A publicitação das primeiras denúncias e o desenvolvimento das investigações, converteu o caso da Petrobras em uma complexa narrativa com episódios principais e secundários, como os casos da compra da refinaria de Pasadena, o episódio do "jatinho" utilizado por André Vargas ${ }^{21}$, o caso Labogen ${ }^{22}$, ou o subescândalo relacionado com a fraude da Comissão Parlamentar de Inquérito destinada a averiguar os desvios na empresa. Neste ponto, é interessante ter em conta a noção de episódio tal como é definido por Reis e Lopes (1988), isto é, uma unidade narrativa não necessariamente demarcada exteriormente, de extensão variável, na qual se narra uma ação autônoma em relação à totalidade da sintagmática narrativa. Os autores sublinham, ainda, que a configuração dos episódios se ajusta, principalmente, a narrativas de composição aberta, o que significa que eles podem ser particularmente visíveis nas narrativas sobre escândalos mais complexos, como aqueles que estamos a analisar.

21 André Vargas viajou com a família para João Pessoa em um jato particular providenciado pelo pivô da operação Lava Jato, Alberto Youssef. O caso levantou suspeitas, já que Alberto Youssef estava a ser investigado pelas autoridades policiais pelos crimes de lavagem de dinheiro. André Vargas acabou por ser condenado a mais de 14 anos de prisão devido ao envolvimento no escândalo.

22 Na edição 2371 de 30/04/2014, Veja noticia que a Polícia Federal suspeita que o ex-ministro Alexandre Padilha e mais dois deputados do PT estariam envolvidos "num golpe milionário contra o Ministério da Saúde" (p. 70), um "golpe" engendrado por Alberto Youssef que teria fundado a Labogen, uma empresa fictícia, e conseguido um contrato de 31 milhões de reais para fornecer medicamentos ao Ministério da Saúde. O esquema serviu, essencialmente, para a evasão de divisas e lavagem de dinheiro, através de negócios fictícios. 
Na nossa perspectiva, um dos episódios mais interessantes do caso Lava Jato surge na edição de 6 de agosto de 2014 sob a manchete "Fraude na CPI da Petrobras". Segundo Veja, a comissão de inquérito entretanto criada para investigar os desvios da empresa "teria sido montada com o intuito de não pegar os corruptos", já que as perguntas feitas pelos senadores foram entregues aos investigados com antecedência, numa "conjuração" que foi gravada em vídeo por alguém que participou na comissão. Este caso é paradigmático no que a serialidade temática do escândalo diz respeito, uma vez que se configura como um episódio relativamente autônomo, demarcado no tempo e no espaço, e com personagens perfeitamente identificadas, como o ex-presidente da empresa, Sérgio Gabrielli ou José Eduardo Barrocas, chefe do escritório da estatal em Brasília. Ao nível de estratégias enunciativas, de notar o recurso à metáfora do teatro para instituir os acontecimentos, um plano lingüístico construído pelo narrador que permite a apreensão da realidade: "Teatro: parecia uma encenação - e era mesmo [...] um escárnio, um teatro" (p. 56-57), conclui o narrador-jornalista.

Após a recomposição da intriga e a identificação de alguns dos seus episódios, podemos analisar a personalização do escândalo e a construção das dramatis personae. Na perspectiva de Thompson (2001), o escândalo midiático tem, necessariamente, dramatis personae, ou indivíduos direta ou indiretamente implicados nas transgressões ou nas denúncias públicas. De resto, as personagens funcionam como "fios de ligação" entre os diferentes episódios, elementos que sustentam o desenrolar e a progressão da "estória" (Reis; Lopes, 1988, p. 154). Elas são o núcleo essencial da progressão narrativa e do desenrolar da "estória", sendo consideradas como "unidades funcionais da narrativa", isto é, como segmentos que desempenham um papel significativo no desenrolar da diegese (Reis; Lopes, 1988, p. 161).

Por conseguinte, várias edições são, a nosso ver, bastante elucidativas acerca da construção do caráter das personagens envolvidas no escândalo da Petrobras, mas também na importância que estas adquirem para a progressão da estória. A voz do narrador apresenta as personagens como indivíduos com consideráveis falhas de caráter, como "corruptos" ou "saqueadores". Alberto Youssef, por exemplo, é apelidado de "o cliente", "um velho conhecido da polícia", enquanto Paulo Roberto Costa, denominado de "arrecadador", é identificado como "personagem central do escândalo", o mediador entre "corruptos" e "corruptores" (02/04/2014, p. 66-67). Já André Vargas, deputado do PT, é descrito como "típico casca grossa", como "alguém sempre pronto a servir aos líderes, aceitando toda a sorte de trabalho sujo, desde que alinhado com o projeto de poder do PT", e "entusiasta do controle social da mídia" (p. 54). Na edição 
seguinte, de 16 de abril de 2014, Veja envolve dois ex-presidentes do Brasil no escândalo. É revelado que a Polícia Federal apreendeu um depósito de 8 mil reais na conta de Fernando Collor de Mello, caracterizado como "decano da turma que confunde o público e o privado sempre em benefício do segundo", e já no final do texto é feita referência a Lula da Silva como "outro mestre das indicações políticas" (p. 70-71).

Por outro lado, Veja recorre frequentemente à identificação e ao posicionamento das personagens do escândalo mediante infografias ${ }^{23}$ e demais ilustrações que facilitam a compreensão do enredo, algo típico na cobertura de escândalos políticos, mas também é notório como o narrador as caracteriza mediante adjetivos e alcunhas, como o "gerente" (Paulo Roberto Costa) ou o "caixa" do esquema (Alberto Youssef). É particularmente evidente como a revista posiciona e caracteriza as personagens do escândalo referindo aspectos negativos do seu caráter, aspectos psicológicos referenciados que fazem parte da estratégia da narração, isto é, que permitem identificar e caracterizar as personagens como "transgressores". As narrativas precisam de personagens que representem determinados papéis no enredo e, no caso de narrativas sobre escândalos políticos, as personagens são normalmente identificadas como "vilões" ou "transgressores". Tal como constata Gomes (2004):

O personagem político pode ser construído a partir da identificação dos elementos constantes, morais e psicológicos, do seu caráter. Os personagens políticos prediletos do jornalismo-espetáculo são, em geral, negativos, o seu caráter (literalmente, as marcas estáveis da sua personalidade)consistefrequentementeemnãotercaráter(nosentido moral do termo). Por isso, a busca da falha gravíssima de conduta, que gera o desejável escândalo político, ou, ainda mais disseminada, a busca da indicação das incoerências do político como forma de identificação de um defeito seu de caráter (Gomes, 2004, p. 350).

\section{Considerações Finais}

Despertando efeitos fáticos ou efeitos poéticos, a reconfiguração dos escândalos produzida pelo campo do jornalismo articula os antecedentes e os consequentes do acontecimento, a temporalidade e a serialidade do desenrolar desses acontecimentos, as ações perpetradas por personagens, ordenando e colocando em relação uma síntese de elementos heterogêneos, dispersos no tempo e fragmentados que, no entanto, são ordenados, são colocados em

23 Vide, por exemplo, o frame visual da edição de 29 de outubro de 2014. 
relação. Como procuramos demonstrar com o seguinte empreendimento, a reconfiguração dos escândalos midiáticos é particularmente sensível a uma lógica narrativa que possibilita a compreensão do mundo prático da ação através de uma rede de intersignificação que integra e articula elementos heterogêneos numa narrativa dramática. Assim, a compreensão e experimentação do escândalo faz-se pela via da narratividade e por uma certa atitude argumentativa do narrador no momento de "costurar" e configurar o acontecimento. Mediante um processo de "tessitura da intriga", o escândalo desenvolve-se, literalmente, nos meios de comunicação que através de determinadas marcas enunciativas, transformam o acontecimento em uma "estória" inteligível, numa "estória" que pode ser apreendida e experienciada pelo público.

Por outro lado, no caso de escândalos midiáticos particularmente complexos, como os processos Face Oculta e Lava Jato, as investigações iniciais podem conduzir a novos indícios ou novas transgressões que acabam por aumentar a complexidade do acontecimento e o próprio quadro enunciativo do escândalo. Este foi, de resto, um dos nossos objetivos essenciais: concentrar a atenção na eclosão dos casos e compreender o seu posterior desdobramento em uma narrativa mais complexa. Acreditamos que, mediante os pressupostos da narratologia, é possível tecer um todo coerente, costurando notícias dispersas sobre um mesmo tema e, por conseguinte, discernir aspectos simbólicos dos escândalos que de outro modo passariam despercebidos. Fios narrativos que, ligados, permitem configurar uma trama e visualizar uma sintaxe narrativa entre notícias dispersas.

Como tivemos oportunidade de constatar, os dois escândalos tiveram início a partir de denúncias de corrupção que acabaram por se converter, do ponto de vista da cobertura informativa, em elementos secundários: em Portugal, a corrupção na adjudicação de obras públicas e a manipulação de concursos; no Brasil, essencialmente as denúncias de subornos da empresa holandesa e a compra suspeita da refinaria de Pasadena noTexas. Posteriormente, importantes reconfigurações semânticas transfiguraram os dois escândalos em narrativas mais complexas que acabaram por envolver os governos dos dois países. De outro modo, é visível como no Face Oculta é a José Sócrates a quem o jornal atribui maior centralidade, tal como ao Partido Socialista enquanto personagem coletiva. Já no Lava Jato, há uma clara tentativa de converter Dilma Rousseff, Lula da Silva e o Partido dos Trabalhadores em personagens centrais da intriga. Em várias edições, os dois veículos culpabilizam o Partido Socialista, no primeiro caso, e o Partido dos Trabalhadores, no segundo, pela existência de denúncias de corrupção na vida pública dos dois países, o que deixa a antever 
um determinado posicionamento político e ideológico do Semanário Sol e da revista Veja face aos dois governos.

Neste ponto, é interessante constatar a prevalência da categoria do conflito como estrutura dramática (Gomes, 2004; Motta; Guazina, 2010), não só do conflito evidente entre atores políticos e jurídicos que se confrontam na arena pública, mas também do conflito bipolar entre a esfera política e o campo da imprensa. Na base da relação de conflito estabelecida entre a esfera jornalística e a esfera política, verifica-se a existência de lutas simbólicas pela conquista de credibilidade, constituindo-se os escândalos como uma forma de legitimação do discurso jornalístico, dos seus valores e da sua função social de campo vigilante do poder político e perfeitamente autônomo face à sua influência.

Por outro lado, na análise à cobertura dos dois escândalos, é notório como no período analisado ambos os processos se pautaram por uma forte midiatização da justiça que acabou por alimentar as duas narrativas. O processo Face Oculta progrediu, essencialmente, devido a fugas de informação e devido à publicidade das escutas telefônicas que envolviam José Sócrates, tal como o caso Lava Jato que tem sido alimentado pela publicidade dos processos de "delação premiada", como a posterior delação da Odebrecht, que voltou a reconfigurar o caso, e pelo "vazamento" de "grampos" telefônicos. Verificou-se, ainda, uma certa circularidade da informação que visou manter os dois casos na agenda pública. Quando não há novas denúncias, os veículos informativos recuperam os principais episódios da trama, em um processo que acabou por "alimentar" a discussão pública sobre os casos, mas que, simultaneamente, também permitiu a progressão das intrigas mediante uma certa serialidade temática.

Para concluir, queremos sugerir que muitas vezes os escândalos políticos se convertem em uma representação com enredos e personagens, mas também com uma dimensão lúdica inerente ao seu cariz extemporâneo que enche os olhos, que é notável e que, por isso mesmo, permite a spectatio, o desfrute visual da dramaturgia política. De outro modo, não devemos esquecer que, na máquina narrativa da mídia, a realidade é mediada por esquemas comunicacionais que enquadram, moldam, configuram, "efabulam" (Vattimo, 1992) e, em alguns casos, deformam a realidade. A experiência midiática é uma realidade em segunda mão e o escândalo não escapa a uma lógica artefatual e de maquiagem inerente às estratégias e artimanhas enunciativas do medium. 


\section{REFERÊNCIAS}

ALLEGRETTI, Fernanda. Propina no fundo do mar. p. 56-59, Veja, 2361, ano 47, n. 8, 19. Fev. 2014.

AZEVEDO, Ana Paula; CABRITA, Felícia. As escutas proibidas. p. 4-6, Semanário Sol, Lisboa, n. 178, 5. Fev. 2010.

. O plano de Sócrates para controlar a TVI e outros grupos de media. p. 4-9, Semanário Sol, Lisboa, n. 179, 12. Fev. 2010.

. Sócrates mentiu ao Parlamento sobre a TVI. p. 4-6, Semanário Sol, Lisboa, n. 166, 13. Nov. 2009.

; CABRITA, Felícia; ROSA, Luís. Sócrates interceptado nas escutas. p. 4-6, Semanário Sol, Lisboa, n. 165, 6. Nov. 2009.

BIRD, Elizabeth. What a story! Understanding the audience for scandal. In LULL, James; HINERMAN, Stephen (Eds). Media Scandals. London: PolityPress, 1997.

BONIN, Robson; RANGEL, Rodrigo; Pereira, Daniel. Um poço de suspeitas, p. 44-51, Veja, 2366, ano 47, n. 13, 26 Mar. 2014.

BONIN, Robson. Youssef: O Planalto sabia de tudo. Delegado: quem do Planalto? Youssef: Lula e Dilma. Veja, p. 68-75, 2397, ano 47, n. 44, 29. Out. 2014.

BONIN, Robson; GASPAR, Malu. A Petrobras desceu a rampa, p. 62-69, Veja, 2367, ano 47, n. 14. 2. Abr. 2014.

CANEL, Maria José; SANDERS, Karen. Morality Tales: political scandals and journalism in Britain and Spain in the 1990s. Broadway: Hampton Press, 2006.

CORREIA, Eduardo. História e Ficção na Narrativa de um Escândalo Midiático, 2012, 410 f. Tese (Doutorado em Comunicação Social), Faculdade de Comunicação, UnB, Brasília, 2012.

Crimes de Responsabilidade [...] Políticos. Assembleia da República, Lisboa, [2017] Disponível em: http://www.parlamento.pt/Legislacao/Documents/Legislacao_ Anotada/CrimesResponsabilidadeTitularesCargosPoliticos_Simples.pdf. Acesso: 2 maio 2017.

FIGUEIREDO, Cândido. Grande Dicionário da Língua Portuguesa. Lisboa: Bertrand, 1996.

GOMES, Wilson. Transformações da Política na era da comunicação de massa. São Paulo: Paulus, 2004.

HABERMAS, Jürgen. Historia y crítica de la opinión pública. La transformación estructural de la vida pública. Barcelona: Editorial Gustavo Gili, 2006. 
LITS, Marc. Du récit au récit médiatique. Bruxelles: Éditions de Boeck Université, 2008.

MARKOVITS, Andrei; SILVERSTEIN, Mark. The Politics of Scandal: Power and Process in Liberal Democracies. New York: Holmes \& Meier Publishers, 1988.

MARQUES, Hugo. A grande farsa, p. 56-63, Veja, 2385, ano 47, n. 32, 6. Ago. 2014.

MESQUITA, Mário. Personagem Jornalística: da Narratologia à Deontologia. In:

O Quarto Equívoco: o poder dos media na sociedade contemporânea. Coimbra: Minerva Coimbra, 2002.

MOTTA, Luis Gonzaga. Análise Crítica da Narrativa. Brasília: Editora UnB, 2013.

; GUAZINA, Liziane. O Conflito como categoria estruturante da narrativa política: o caso do Jornal Nacional. Brazilian Journalism Research, Brasília, v. 6, n. 1, p. 132-149, 2010.

PRIOR, Hélder. Publicidade política e estratégias de representação: a visibilidade pública como armadilha, Contemporânea - Revista de Comunicação e Cultura, Salvador, v. 9, n. 3, p. 405-416, dez. 2011.

. Esfera Pública e Escândalo Político: a Face Oculta do Poder. Ramada, Lisboa: Media XXI, 2016.

. O Escândalo Político como experiência narrativa. Brazilian Journalism Research, Brasília, v. 11, n. 2, 2015.

RANGEL, Rodrigo. Peixe grande na rede, p. 70-73, Veja, 2371, ano 47, n. 18, 30. Abr. 2014.

; MARQUES, Hugo. O objetivo é o caixa dois, p. 66-73, Veja, 2369, ano 47, n. 16, 16. Abr. 2014.

REIS, Carlos; LOPES, Ana. Dicionário de Teoria da Narrativa. São Paulo: Editora Ática, 1988.

Relatório final [...], 2010. Esquerda.net, Lisboa, 2010. Disponível em: http://www. esquerda.net/sites/default/files/relatorio_cpi_pt_tvi.pdf. Acesso em: 2 maio 2017.

RICOEUR, Paul. Du texte à l'action. Essais d'herméneutique II. Paris: Édition du Seuil, 1986.

SANCHÉZ, Jiménez. Detrás del Escándalo Político: Opinión Pública, Diñero y Poder em España del siglo XX. Barcelona: Tusquets Editores, 1995.

The Portuguese Living Webster Encyclopedic Dictionary of the English Language. Bertrand, 1974. 
THOMPSON, John. El Escándalo Político: Poder y visibilidade em la era de los medios de comunicación. Barcelona: Paidós, 2001.

The nature of political scandal. In: NEGRINE, Ralph; STANYER, James (Eds). The Political Communication Reader. London and New York: Routledge, 2007.

TODOROV, Tzvetan. As Estruturas Narrativas. São Paulo: Editora Prespectiva, 1979.

VAN DIJK, Teun. Estructuras e Funciones del Discurso. Madrid: Siglo Veintiuno Editores, 1998.

VATTIMO, Gianni. A Sociedade Transparente. Lisboa: Relógio D’Água Editores, 1992.

Recebido em: 8/8/2017

Aceito em: 10/8/2017

Dados do autor:

Hélder Prior | helder.prior@gmail.com

Pós-Doutor em Comunicação pela Universidade de Braśilia (PNPD/CAPES), Doutor (2013) em Ciências da Comunicação pela Universidade da Beira Interior, Portugal. Membro da junta diretiva da Asociación Latinoamericana de Investigadores en

Campañas Electorales (ALICE). Investigador de Pós-Doutoramento na Fundação para a Ciência e a Tecnologia.

Laboratório de Comunicação Online da Universidade da Beira Interior

Universidade da Beira Interior (UBI)

Rua Marquês D'Ávila e Bolama

6201-001 - Covilhã - Portugal 